heat-flow method to the determination of thermal conductivities to temperatures of the order of $1700^{\circ} \mathrm{C}$. is being installed and in the Temperature Measurement Section the investigation of the relative merits of the boiling point of sulphur $\left(444.600^{\circ} \mathrm{C}\right.$.) and the freezing point of zinc $\left(419.50^{\circ} \mathrm{C}\right.$.) $\mathrm{as}$ a primary fixed point is continuing. Measurements have been made of the elasticity of tiny single crystals such as sapphire and diamond, and of the elastic constants of single crystals of pure copper, copper-zinc and copper-gallium alloys. The Ship Division reports a delay of five to six months in the putting in hand of resistance and propulsion tests for shipbuilders. The delay is because of an increased demand for tests and because of the introduction of the five-day week in the Laboratory. The investigation of the effect of various structural roughnesses on the beheviour of ships' hulls has yielded some interesting information. For small ships the resistance of an all-riveted hull can be as much as 10 per cent grester than for an allwelded hull, and for larger and faster shipe it may be as much as 25 per cent greater.

Finally, the annual report, which is presented in an attractive cover and is illustrated, concludes with a report of the Test House, indicating the significant increase in the variety of precision instruments submitted for test to the Laboratory.

S. WEINTBOUB

\title{
UNIVERSITIES OF LATIN AMERICA
}

\begin{abstract}
LTHOUGH the nations of Latin America are of recent growth they inherit an ancient university tradition. Almost as soon as the Spaniards had completed the first of their settlements in La Española (Hispaniola), a Bull issued by Pope Paul III in 1538 transformed the island's Dominican college into the University of St. Thomas Aquinas. Not long after Hermán Cortés's conquest of Mexico and Pizarro's extinction of the Ince Empire in Peru, the Emperor Charles $V$ established universities in his two new Americen kingdoms: Mexico City held its first classes in 1553 and San Marcos was functioning actively by 1578. The oldest Latin American universities are coeval with the oldest Scottish universities and antedate many famous European centres of higher learning. An account of them has been given by J. C. J. Metford of the University of Bristol (The Universities Review, 30, No. 1, October 1957).
\end{abstract}

As Spanish settlements expanded all over America, the Dominicans, Jesuits and Franciscans founded schools attached to their monasteries. Before the sixteenth century had ended, their colegios were to be found in places so far apart as Antigua, on the isthmus of Central America, Chuquisaca, in the lofty silver mining region of Bolivia, and Córdoba, in the foothills of the Andes. There, and in many other centres, courses in the arts, grammar, philosophy and theology were being delivered almost as soon as the townships were marked out in their characteristic grid-iron pattern. The colegios grew with the towns, and, in the eighteenth century, many colegios were granted the status of Royal and Pontifical universities. By the end of the colonial period, there was scarcely a region of importance in the Spanish American Empire without its university, or college, where advanced studies could be pursued.

As in Europe, the universities and colleges of Spanish America had their periods of brilliance and their times of decline, but, on the whole, they did not compare unfavourably with universities in the Old World. Although dependent upon endowments, or grants from royal, vice-regal or ecclesiastical treasuries, they enjoyed a reasonable messure of independence in the management of their internal affairs and in the granting of degrees. Their chief function was to train aspirants to the priesthood or candidates for higher theological degrees. Science was not wholly neglected: mathematics and astronomy were studied, and much work was accomplished on the curative plants and herbs known to the Indians.
From an early date in Mexico City and Lima, there were ohairs for the study of Indian languages, but the intention was to use this knowledge in the evangelizetion of the aborigines. University teachers were drawn chiefly from the ranks of the Dominicans and the Jesuits, but, in the eighteenth century, lay professors were not unknown.

Independence from Spain and Portugal caused little change in the social structure of the former American colonies, except that the wealthy criollo minority succeeded to positions which were previously the perquisites of peninsular Spaniards and Portuguese. Much lip-service was paid to the catchwords of freedom, equality and the pursuit of happiness, but little was done towards the realization of these ideals, except, to some extent, in the field of education. Nurtured in French, North Americen and British radical traditions, the fathers of the revolution believed sincerely in the power of education to spread enlightenment. The University of Buenos Aires was founded in 1821 by men associated with Rivadavia, who had corresponded with Jeremy Bentham. Bolivar founded the Universities of Cartagena, in Columbia and Trufillo, in Peru. His lieutenant, General Santander, established the University of Cauca. Political upheavals, anarchy, the rise of dictators and empty treasuries eventually terminated these ambitious schemes. Despite men like Andrés Bello, in Columbia and Chile, Sarmiento and Alberdi, in Argentina, and the Emperor Don Pedro II, in Brazil, little was accomplished, so far as universities were concerned, until the second half of the nineteenth century.

By that time, some of the mejor nations-Argentina, Brazil and Chilo-had stabilized their domestic affairs and had grown in wealth and importence. The need, the means and the will to improve educational facilities followed. Institutions of higher learning and universitios were created in the principal States. In Bolivia and Brazil, the tendency was to establish degree-granting faculties instead of universities.

The most significant event in the history of the modern universities was the reform movement which began in Cordoba, Argentina, in 1918. Essentially, it was the work of young men, who looked upon themselves as the harbingers of the new Latin America which would be fundamentally American, freed from dependence on Europe and purged of inherent abuses. They were all greatly influenced by the iconoclasm of the Spanish writer and thinker, 
Miguel de Unamuno. Much of their educational outlook derived from the works of Ortega y Grsset. Practical measures were embodied in Argentine law between 1919 and 1922 . From Argentina, the reform movement spread to many other Latin American countries and influenced legislation on university government especially in Bolivia, Colombia and Cuba.

The Second World War brought far-reaching changes in the life of Latin America which were not without their impact on the growth of universities. High prices from the belligerents for raw materials meant an astronomical increase in national wealth. At the same time, attempts were made to create locally industries for the production of commodities which had hitherto been imported. To fulfil these national and industrial ambitions, a supply of university-trained men would be needed. With this in mind, some of the more perspicacious governments arranged that part of the newly acquired wealth should be diverted either to the improvement of existing institutions or to the creation of new universities. The best examples of this new policy are the superlative modern buildings constructed for the University of São Paulo in the midst of Brazil's rapidly growing industrial area.

To-day, there is no country in Latin America without at least one university. There are eighty. eight throughout the region, although some have only two or three faculties and some are little more than a loose confederation of otherwise independent faculties. The largest institutions, with more than ten thousand students each, are the National University of Mexico and the Universities of Havana, Buenos Aires and La Plata. Argentina has at least three other universities with between five and ten thousand students each, and Uruguay, Chile and Peru one university each of comparable size.

Nearly all of them have important features in common-they are part of the State system of educa. tion, their powers and functions are carefully prescribed by law, and they are mostly subject to direct interference by the president of the nation, the ministry of education, or some governmental equivalent. The exceptions are the so-called universidades particulares, or private universities, of which the University of Concepcion, Chile, is the best secular example. The majority are Roman Catholic (for example, Santiago de Chile, Lima, Bogota), either concerned with the education of priests or founded to preserve the faithful from the militant secularism characterizing some of the State universities, which were controlled by positivists, humanists and others hostile to clerical influences in education. A certain measure of government control is nevertheless exercised through the State recognition of their degrees.

State control is also clearly seen in finance. Universities generally are dependent on the State for practically three-quarters of their annual income.

As in Spain and Portugal, the teacher in Latin America, whether at school or university level, enjoys a degree of respect, almost veneration, unknown to his counterparts in Anglo-Saxon countries, but the esteem in which he is held is in inverse proportion to the rewards of his profession. University teaching therefore becomes a part-time occupation, as few men of standing would be content to exist on $a_{6}$ meagre university salary. Most teachers are professional men-lawyers, doctors, engineers, or even novelists or journalists - who spare a few hours a day for their classes, or perhaps leave them to a trusted assistant.

Most students come from the urban conglomerations around the university and live at home or with relatives. Newly planned campuses now include residencias, but these are exceptional. Usually, the student has some part-time employment, often connected with the profession for which he is preparing himself, and, towards the end of his course, he may be married, with a young family of his own. Lack of continuity often characterizes a student's career, as his circumstances or predilections change, and he may remain a student for a surprisingly long time. This, in some measure, explains the high enrolment figures announced by some institutions. The University of Mexico City thus claims more than 22,000 students, a high proportion of whom are unlikely to be full-time.

\section{OVERSEAS SERVICE IN BRITISH COLONIAL TERRITORIES}

\begin{abstract}
$\mathrm{T}$ HE Overseas Service Bill, which received an unopposed second reading in the House of Commons on January 21 , is an enabling Bill to implement the policy outlined in the White Paper of May 1956 on the Overseas Civil Service. In moving the second reading, the Secretary of State for the Colonies, Mr. A. Lennox-Boyd, said that formidable difficulties had been encountered in the proposed policy for a central register and pool, particularly in guaranteeing a continuing career, that is, a succession of jobs of ascending importance and level of responsibility for an officer recruited into the central pool initially for a particular job in a particular territory. On March 26, 1957, the Lord Privy Seal had announced that the creation of a pool of administrative and technical officers must await evidence of substantial demand for their services and that regular employment for them could be foreseen for several years. Meanwhile, Clauses 2 and 3 of the Bill provided for the making of Orders to govern pensions
\end{abstract}

earned while in the Overseas Service and for the preservation of pension rights already acquired. When the Bill became law the Governments of the Colonies would be asked to enact comparable legislation. Clause 4 contained special provisions relating to police officers and Clause 6 covered the appointment of officers to a wide variety of public services under overseas Governments, municipal or local authorities or public corporations or to any Federal Government or outside authority such as the East African High Commission.

Mr. Lenrox Boyd said that at the constitutional conference last June he had signed agreements for special lists with the four Nigerian Governments but so far only about 120 out of the 2,000 eligible pensionable officers in the service of these Governments had applied to join. Sir John Martin was in Nigeria examining the position, and the application of the special list procedure was the subject of current negotiations with the Grovernment of Malaya. In 